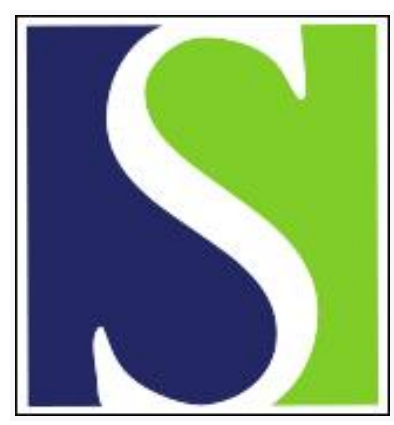

Scand J Work Environ Health 1993;19(2):108-114

https://doi.org/10.5271/sjweh.1499

Issue date: 01 Apr 1993

Role of the herbicide atrazine in the development of non-Hodgkin's lymphoma.

by Hoar Zahm S, Weisenburger DD, Cantor KP, Holmes FF, Blair A

Affiliation: Environmental Epidemiology Branch, National Cancer Institute, Rockville, Maryland 20892.

The following article refers to this text: 1994;20(3):223-226

Key terms: agriculture; atrazine; cancer; case-referent study; epidemiology; herbicide; herbicide atrazine; non-Hodgkin's lymphoma; occupation; triazine

This article in PubMed: www.ncbi.nlm.nih.gov/pubmed/8316777 


\title{
Role of the herbicide atrazine in the development of non-Hodgkin's lymphoma'
}

\author{
by Shelia Hoar Zahm, ScD, ${ }^{2}$ Dennis D Weisenburger, MD, ${ }^{3}$ Kenneth $\mathrm{P}$ Cantor, $\mathrm{PhD},{ }^{2}$ \\ Frederick F Holmes, MD, ${ }^{4}$ Aaron Blair, $\mathrm{PhD}^{4}$
}

\begin{abstract}
HOAR ZAHM S, WEISENBURGER DD, CANTOR KP, HOLMES FF, BLAIR A. Role of the herbicide atrazine in the development of non-Hodgkin's lymphoma. Scand $J$ Work Environ Health 1993;19:108 - 14. Atrazine is the most commonly used herbicide in the United States and is a widespread groundwater contaminant in the Midwest. The role of atrazine in the development of human non-Hodgkin's lymphoma (NHL) was investigated in three case-referent studies conducted in four midwestern states in the United States. A total of 993 white men with NHL and 2918 populationbased referents were interviewed concerning their agricultural practices. When the results of the three studies were combined, atrazine use was associated with an odds ratio of 1.4 [95\% confidence interval (95\% CI) $1.1-1.8,130$ cases, 249 referents) for NHL. However, adjustments for the use of 2,4dichlorophenoxyacetic acid and organophosphate insecticides reduced the apparent association between NHL and atrazine in all but one state and reduced the associations for the long-term and frequent users in Nebraska. Detailed analyses suggested that there was little or no increase in the risk of NHL attributable to the agricultural use of atrazine.
\end{abstract}

Key terms: agriculture, cancer, case-referent study, epidemiology, herbicides, occupation, triazines.

In 1990 , over 75 million pounds (34 million kilograms) of the triazine herbicide atrazine was used in the United States for weed control on corn, sorghum, sugarcane, macadamias, and pineapple $(1-3)$. Over two-thirds of the use was associated with corn (4). Atrazine was also used on golf courses, lawns, pastureland, and in Christmas-tree production (3). Atrazine is the most commonly used herbicide in the United States (1) and is a widespread groundwater contaminant in the Midwest (3). The use of atrazine in Germany (5) and parts of Italy (P Crosignani, personal communication, 1990) has been banned to prevent further groundwater contamination.

Atrazine forms genotoxic $\mathrm{N}$-Nitroso compounds under certain conditions (6-7) and has been shown to increase the incidence of malignant mammary tumors in female Sprague Dawley rats (8), benign mammary tumors in male Fisher 344/LATI rats (9), and uterine adenocarcinomas and lymphatic and he-

1 Presented at the Third International Symposium: Issues in Health, Safety, and Agriculture, 10-15 May 1992, Saskatoon, Saskatchewan, Canada.

2 Environmental Epidemiology Branch, National Cancer Institute, Rockville, Maryland, United States.

3 Department of Pathology and Microbiology, University of Nebraska Medical Center, Omaha, Nebraska, United States.

4 Cancer Data Service, University of Kansas Medical Center, Kansas City, Kansas, United States.

Reprint requests to: Dr S Hoar Zahm, Occupational Studies Section, National Cancer Institute, Executive Plaza North, Room 418, Rockville, MD 20892, USA. matopoietic malignancies in female Fisher 344/LATI rats (9). Lymphomas have also been found to occur in excess in male and female Swiss mice $(10,11)$, but the International Agency for Research on Cancer (12) has noted that these results have limitations.

Atrazine may play a role in hormonally mediated tumors, such as breast, endometrium, ovary, and prostatic cancer, because of its action on the hypothalamic-pituitary-gonadal axis (12). Atrazine and its metabolite impair steriod hormone metabolism (12). Atrazine has been shown to inhibit 5-alpha-steroid reductase in the pituitary of rats, reduce 3 alpha-hydroxysteroid dehydrogenase activity in pups, and decrease the number of androgen-specific binding sites in the prostate of pups (12). In vitro studies have also shown atrazine to inhibit androgen metabolism (12). While atrazine inhibits some hormones, it appears to induce others. Notably it causes increases in luteinizing hormone and follicular-stimulating hormone (13).

In humans, atrazine has been linked to ovarian cancer (14), colon cancer (15), and non-Hodgkin's lymphoma (16), and it is currently classified as a possible human carcinogen by the United States Environmental Protection Agency (class C) (1) and by the International Agency for Research on Cancer (group 2B) (12).

The association of atrazine with non-Hodgkin's lymphoma was observed in a case-referent study conducted in Kansas (16). Subsequently, two additional case-referent studies of non-Hodgkin's lymphoma, using similar study designs, were conducted in three other midwestern states (Nebraska, Iowa, and Minnesota) of the United States (17-18). In this report, 
we have combined the data from these three studies to evaluate the role of atrazine in the development of non-Hodgkin's lymphoma.

\section{Subjects and methods}

The three studies evaluated in this report were population-based case-referent studies conducted in $\mathrm{Ne}$ braska, Iowa-Minnesota, and Kansas. Detailed descriptions of the methods for each study have been published elsewhere $(16-24)$. Each study included several malignancies of the lymphatic and hematopoietic systems and, in Kansas only, soft-tissue sarcoma. The studies in Iowa-Minnesota and Kansas included white men, while the Nebraska study included both white men and white women. This report evaluates non-Hodgkin's lymphoma among white men.

\section{Cases}

In Nebraska, all cases of non-Hodgkin's lymphoma diagnosed between 1 July 1983 and 30 June 1986 among white men aged 21 years or older and residing in one of the 66 counties of eastern Nebraska were identified through the Nebraska Lymphoma Study Group and area hospitals $(\mathrm{N}=227)$ (table 1$)$. In the Iowa-Minnesota study, all newly diagnosed cases of non-Hodgkin's lymphoma among white men, aged 30 years or older, were ascertained from records of the Iowa State Health Registry and a special surveillance of records $(\mathrm{N}=780)$ from Minnesota hospitals and pathology laboratories. The diagnosis period for eligibility was March 1981 through October 1983 in Iowa and October 1980 through September 1982 in Minnesota. In Minnesota, non-Hodgkin's lymphoma patients who resided in the cities of Minneapolis, St Paul, Duluth, or Rochester at the time of diagnosis were excluded. In Kansas, all cases of non-Hodgkin's lymphoma diagnosed from 1979 through 1981 among white men aged 21 years or older were identified through the University of Kansas Cancer Data Service, which has a register covering the state of Kansas. A random sample of 200 men was drawn from the 297 non-Hodgkin's lymphoma cases diagnosed in Kansas during the eligible time period.

The cases were reviewed by expert pathologists and classified according to what is called the Working Formulation (25-27). Analyses of follicular (Working Formulation categories B-D), diffuse (Working Formulation categories A, E-G), and other (Working Formulation categories $\mathrm{H}-\mathrm{K}$ ) non-Hodgkin's lymphoma are presented. Only histologically confirmed cases were included. The number of confirmed cases was 220 in Nebraska and 172 in Kansas. In Iowa-Minnesota, the pathology review occurred after interviews were obtained for the nonHodgkin's lymphoma cases. Because the cases for which there was no interview did not undergo pathology review, the total number of eligible histologically confirmed cases could not be determined.

\section{Referents}

The referents were randomly selected from the same geographic areas as the cases, with frequency matching by race, gender, five-year age group, and vital status at the time of the interview. For living cases under 65 years of age, referents were selected by two-stage random digit dialing (28). For living cases aged 65 years or older, the referents were select ed from records of the Health Care Financing Administration (Medicare). For the deceased cases, the referents were selected from state mortality files with additional matching for year of death. Persons with the cause death listed as a malignancy under study or, in Kansas and Nebraska, a malignancy of an illdefined site, homicide, suicide, or legal intervention were excluded. A total of 3379 referents (Nebraska 831 , Kansas 1005, Iowa-Minnesota 1543) were identified.

\section{Interview}

Interviews were conducted with the subjects or their next-of-kin if the subjects were deceased or incapacitated. The interviews were done by telephone in Nebraska and Kansas and in-person in Iowa-Minnesota. In Nebraska, 201 non-Hodgkin's lymphoma patients and 725 referents were interviewed, yielding interview response rates of 91 and $87 \%$, respectively. The overall referent response rate, which accounted for the $91 \%$ response rate in the household census phase of the random digit-dialing procedure, was $85 \%$. In Kansas, 170 patients and 948 referents were interviewed, yielding interview response rates of 96 and $94 \%$, respectively. The random digit-dialing household census had a $92.3 \%$ response rate,

Table 1. Number of Non-Hodgkin's lymphoma cases and referents and their response rates in the case-referent studies in Nebraska, Kansas, and lowa-Minnesota.

\begin{tabular}{|c|c|c|c|c|c|c|}
\hline & \multicolumn{2}{|c|}{ Nebraska } & \multicolumn{2}{|c|}{ Kansas } & \multicolumn{2}{|c|}{$\begin{array}{l}\text { lowa- } \\
\text { Minnesota }\end{array}$} \\
\hline & $\mathrm{N}$ & $\%$ & $\mathbf{N}$ & $\%$ & $\mathrm{~N}$ & $\%$ \\
\hline Cases identified & 227 & - & 200 & . & 780 & $\cdot$ \\
\hline $\begin{array}{l}\text { Histologically } \\
\text { confirmed }\end{array}$ & 220 & - & 172 & . & $\cdots a$ & $\cdot$ \\
\hline Interviewed & 201 & $\cdot$ & 170 & · & 622 & . \\
\hline $\begin{array}{l}\text { Interview response } \\
\text { rate }\end{array}$ & - & 91 & - & $96^{b}$ & $\cdot$ & 89 \\
\hline Referents identified & 831 & $\cdot$ & 1005 & . & 1543 & $\cdot$ \\
\hline Interviewed & 725 & . & 948 & . & 1245 & $\cdot$ \\
\hline $\begin{array}{l}\text { Interview response } \\
\text { rate }\end{array}$ & $\cdot$ & 87 & $\cdot$ & 94 & $\cdot$ & 81 \\
\hline $\begin{array}{l}\text { Overall referent } \\
\text { response rate }\end{array}$ & - & 85 & · & 90 & . & 78 \\
\hline
\end{tabular}

a Pathology review occurred after the interviews were conducted. Cases

bithout interview did not undergo pathology review. firmed non-Hodgkin's lymphoma cases initially diagnosed as nonHodgkin's lymphoma and five non-Hodgkin's lymphoma cases initially diagnosed as other cancer types in the study (eg, Hodgkin's disease). 
which made the overall referent response rate $90 \%$. In Iowa-Minnesota, 780 presumptive non-Hodgkin's lymphoma cases were ascertained, and an interview was obtained for $694(89 \%)$. After pathology review of the cases with interviews 622 cases were confirmed as non-Hodgkin's lymphoma. Interviews were also obtained from 1245 referents $(81 \%)$ in IowaMinnesota. The overall referent response rate, accounting for the $87.5 \%$ household census response rate, was $78 \%$. When the three studies were combined, interviews were obtained from 993 eligible cases and 2918 referents.

In each study, the interviews included detailed questions on agricultural practices. In Nebraska, the use of atrazine on the farm where the subjects lived or worked was ascertained via an open-ended question which did not name specific herbicides, followed by a series of questions in which the interviewer named specific herbicides, including atrazine. Users were further questioned concerning the years of atrazine use, the average annual number of days of use on the farm, and the average annual number of days that atrazine was personally handled (ie, mixed or applied). In Kansas, the use of atrazine was assessed by an open-ended question without any prompting for specific herbicides. Duration of use, days per year of exposure (no further definition of exposure was given the subjects), and other information related to exposure was obtained for all herbicides as a group, but not for atrazine specifically. In Iowa-Minnesota, the use of atrazine was assessed by a direct question naming atrazine. Users were asked the first and last year of atrazine use, the method of application, whether the subject had personally applied, mixed, or handled atrazine, and whether protective equipment was used.

\section{Risk measurement}

The measure of association was the odds ratio (OR). After the subjects from the three studies were combined, risk estimates for atrazine use were adjusted for the effects of age $(<45,45-64$, and $>64$ years) and state (four) by stratification. To adjust for agricultural exposures other than atrazine, the analyses were restricted to farmers and the stratification factors were expanded to include the use of 2,4-dichlorophenoxyacetic acid $(2,4-D)$ or organophosphate insecticides. Maximum-likelihood estimates of the overall risk and $95 \%$ confidence intervals $(95 \% \mathrm{CI})$ were obtained with the EPITOME program (29). Because the methods for obtaining duration and other use characteristics varied in the three studies, we did not combine these data for analysis, but have presented the relevant results for Nebraska separately.

\section{Results}

When the data from the three studies are combined, 101 non-Hodgkin's lymphoma patients and 214 ref- erents reported that atrazine was used on the farms where they lived or worked, yielding an OR of 1.4 (95\% CI 1.1-1.8) (table 2). The OR values ranged from a low of $1.2(95 \%$ CI $0.8-1.8)$ in Iowa to a high of 2.7 (95\% CI 1.2-5.9) in Kansas. There was no change in the OR (OR 1.4) when the analyses were restricted to the 94 patients and 190 referents who reported that they had personally handled atrazine. For two states and for all of the states combined, the risks were greater among the farmers who used atrazine in their farming operations but did not handle it than among farmers who personally handled atrazine.

The percentage of farmers reporting atrazine use varied by study and appeared to be related to the methods used to ascertain pesticide history. In Kansas, $6 \%$ of the referents volunteered a history of atrazine use in response to an open-ended question. In Iowa-Minnesota, $16 \%$ of the referents reported atrazine use after being asked about atrazine specifically. In Nebraska, $6 \%$ of the referents volunteered a history of use and an additional 7\% reported use when asked directly about atrazine, for a total of $13 \%$ of the referents. The risk of non-Hodgkin's lymphoma among the Nebraska subjects who volunteered a history of atrazine use (OR 1.5, 14 cases, 33 referents) was similar to that of the subjects who responded to a direct question about atrazine (OR 1.3, 15 cases, 36 referents).

When all of the states were combined, atrazine use was associated with OR values of 1.3 and 2.0 among the living and deceased subjects, respectively. For all of the subjects, adjustment for a history of hematopoietic or lymphatic cancer in a next-of-kin caused little change in the OR for atrazine use (OR 1.5, 95\% CI 1.1-1.9). There was little variation in the risk of non-Hodgkin's lymphoma by histological type, although diffuse non-Hodgkin's lymphoma demonstrated the strongest association with atrazine use (OR 1.6, 95\% CI 1.1-2.2) (table 3).

In addition to atrazine, the farmers could have been exposed to other herbicides and insecticides, some of which are suspected of increasing the risk of non-Hodgkin's lymphoma (30). In particular, associations between non-Hodgkin's lymphoma and organophosphate insecticides $(\mathrm{OR}=$ Nebraska 2.0, Kansas 1.8, Minnesota 1.5, Iowa 1.3, total 1.5) and the herbicide 2,4-D (OR = Nebraska 1.4, Kansas 2.3, Minnesota 1.1, Iowa 1.0 , total 1.2) were noted. To adjust for these other agricultural exposures, the analyses were restricted to farmers. Among the farmers with non-Hodgkin's lymphoma, 57\% had never used atrazine, 2,4-D or organophosphate insecticides, 17\% had used at least one of the exposures of interest, $14 \%$ had used two of the three, and $12 \%$ reported using all three. Among the farmer referents, $70 \%$ had never used atrazine, 2,4-D or organophosphate insecticides, $15 \%$ had used at least one, $7 \%$ had used two of the three, and $7 \%$ reported using all three. When the farmers who used atrazine were compared with 
Table 2. Number of non-Hodgkin's lymphoma cases and referents and the odds ratios (OR) and $95 \%$ confidence intervals (95\% $\mathrm{Cl}$ ) according to atrazine use among white men in eastern Nebraska, lowa, Minnesota, and Kansas.

\begin{tabular}{|c|c|c|c|c|}
\hline & $\begin{array}{l}\text { Referents } \\
\text { (N) }\end{array}$ & $\begin{array}{l}\text { Non-Hodgkin's lymphoma } \\
\text { cases } \\
(\mathrm{N})\end{array}$ & OR & $95 \% \mathrm{Cl}$ \\
\hline \multicolumn{5}{|l|}{ Nebraska } \\
\hline Nonfarmers & 184 & 54 & $\cdot$ & . \\
\hline \multicolumn{5}{|l|}{ Farmers } \\
\hline $\begin{array}{l}\text { Used atrazine } \\
\text { Personally handled atrazine } \\
\text { Used but did not handle atrazine }\end{array}$ & $\begin{array}{l}69 \\
54 \\
15\end{array}$ & $\begin{array}{r}29 \\
23 \\
6\end{array}$ & $\begin{array}{l}1.4^{\mathrm{a}} \\
1.5^{\mathrm{a}} \\
1.3^{\mathrm{a}}\end{array}$ & $\begin{array}{l}0.8-2.5 \\
0.8-2.7 \\
0.5-3.4\end{array}$ \\
\hline \multicolumn{5}{|l|}{ lowa } \\
\hline Nonfarmers & 255 & 120 & $\cdot$ & $\cdot$ \\
\hline \multicolumn{5}{|l|}{ Farmers } \\
\hline $\begin{array}{l}\text { Used atrazine } \\
\text { Personally handled atrazine } \\
\text { Used but did not handle atrazine }\end{array}$ & $\begin{array}{l}90 \\
72 \\
18\end{array}$ & $\begin{array}{l}52 \\
36 \\
16\end{array}$ & $\begin{array}{l}1.2^{\mathrm{a}} \\
1.0^{\mathrm{a}} \\
1.8^{\mathrm{a}}\end{array}$ & $\begin{array}{l}0.8-1.8 \\
0.7-1.7 \\
0.9-3.7\end{array}$ \\
\hline \multicolumn{5}{|l|}{ Minnesota } \\
\hline Nonfarmers & 292 & 146 & . & . \\
\hline \multicolumn{5}{|l|}{ Farmers } \\
\hline $\begin{array}{l}\text { Used atrazine } \\
\text { Personally handled atrazine } \\
\text { Used but did not handle atrazine }\end{array}$ & $\begin{array}{l}53 \\
36 \\
17\end{array}$ & $\begin{array}{l}36 \\
23 \\
13\end{array}$ & $\begin{array}{l}1.4^{\mathrm{a}} \\
1.3^{\mathrm{a}} \\
1.6^{\mathrm{a}}\end{array}$ & $\begin{array}{l}0.9-2.2 \\
0.7-2.2 \\
0.7-3.2\end{array}$ \\
\hline \multicolumn{5}{|l|}{ Kansas } \\
\hline Nonfarmers & 286 & 37 & $\cdot$ & . \\
\hline \multicolumn{5}{|l|}{ Farmers } \\
\hline $\begin{array}{l}\text { Used atrazine } \\
\text { Personally handled atrazine } \\
\text { Used but did not handle atrazine }\end{array}$ & $\begin{array}{r}37 \\
28 \\
9\end{array}$ & $\begin{array}{r}13 \\
12 \\
1\end{array}$ & $\begin{array}{l}2.7^{\mathrm{a}} \\
3.2^{\mathrm{a}} \\
0.9^{\mathrm{a}}\end{array}$ & $\begin{array}{l}1.2-5.9 \\
1.4-7.4 \\
0.1-5.8\end{array}$ \\
\hline \multicolumn{5}{|l|}{ Total } \\
\hline Nonfarmers & 1017 & 357 & . & . \\
\hline \multicolumn{5}{|l|}{ Farmers } \\
\hline $\begin{array}{l}\text { Used atrazine } \\
\text { Personally handled atrazine } \\
\text { Used but did not handle atrazine }\end{array}$ & $\begin{array}{r}249 \\
190 \\
59\end{array}$ & $\begin{array}{r}130 \\
94 \\
36\end{array}$ & $\begin{array}{l}1.4^{\mathrm{c}} \\
1.4^{\mathrm{c}} \\
1.6^{\mathrm{c}}\end{array}$ & $\begin{array}{l}1.1-1.8 \\
1.0-1.8 \\
1.0-2.4\end{array}$ \\
\hline
\end{tabular}

a Adjusted for age.

b Personally handled status was specific for atrazine in all of the states except Kansas, where it refered to usual practice for all herbicides as a group.

c Adjusted for age and state.

Table 3. Number of non-Hodgkin's lymphoma cases and referents and odds ratios (OR) and $95 \%$ confidence intervals (95\% $\mathrm{Cl}$ ) by histologic type according to atrazine use among men in eastern Nebraska, lowa and Minnesota, and Kansas.

\begin{tabular}{|c|c|c|c|c|c|c|c|c|c|c|c|}
\hline & & & \multicolumn{9}{|c|}{ Non-Hodgkin's lymphoma cases } \\
\hline & \multicolumn{2}{|c|}{ Referents } & \multicolumn{3}{|c|}{ Follicular type } & \multicolumn{3}{|c|}{ Diffuse type } & \multicolumn{3}{|c|}{ Other type } \\
\hline & $\mathrm{N}$ & $\mathrm{OR}^{\mathrm{a}}$ & $\mathrm{N}$ & $\mathrm{OR}^{\mathrm{a}}$ & $95 \% \mathrm{Cl}$ & $\mathrm{N}$ & $\mathrm{OR}^{\mathrm{a}}$ & $95 \% \mathrm{Cl}$ & $\mathrm{N}$ & $\mathrm{OR}^{\mathrm{a}}$ & $95 \% \mathrm{Cl}$ \\
\hline Nonfarmers & 1017 & · & 117 & . & · & 158 & . & . & 82 & · & · \\
\hline $\begin{array}{l}\text { Farmers who used } \\
\text { atrazine }\end{array}$ & 249 & 1.0 & 40 & 1.3 & $0.9-1.9$ & 66 & 1.6 & $1.1-2.2$ & 24 & 1.1 & $0.7-1.8$ \\
\hline
\end{tabular}

a Adjusted for age and state.

the farmers who did not, the OR, adjusted for age and state, was $1.5(95 \%$ CI $1.1-1.9)$ (table 4$)$. The risks were about the same after the farmers who used atrazine in their farming operation but did not handle it personally were eliminated. When the OR values were also adjusted for the use of 2,4-D and organophosphate insecticides, the OR was reduced to $1.2(95 \% \mathrm{CI} 0.9-1.7)$. Adjustment for 2,4-D use re- duced the OR values in Nebraska and Kansas, while adjustment for organophosphate insecticide use reduced the OR values in Nebraska, Iowa, and Minnesota.

Table 5 presents the risk of non-Hodgkin's lymphoma associated with the characteristics of atrazine use in Nebraska, the state with the most detailed information on the duration and annual frequency of 
Table 4. Number of non-Hodgkin's lymphoma cases and referents and the odds ratios (OR) and $95 \%$ confidence intervals (95\% $\mathrm{Cl}$ ) according to state and atrazine use among male farmers, as adjusted for age and use of 2,4-dichlorophenoxyacetic acid (2,4-D) and organophosphate insecticides.

\begin{tabular}{|c|c|c|c|c|c|c|c|c|c|c|}
\hline Farmers & $\begin{array}{l}\text { Refer- } \\
\text { ents } \\
\text { (N) }\end{array}$ & $\begin{array}{l}\text { Cases } \\
(\mathrm{N})\end{array}$ & $\begin{array}{c}\text { OR } \\
\text { adjusted } \\
\text { for age }\end{array}$ & $\begin{array}{c}95 \% \mathrm{Cl} \\
\text { for } \mathrm{OR} \\
\text { adjusted } \\
\text { for age }\end{array}$ & $\begin{array}{c}\text { OR } \\
\text { adjusted } \\
\text { for age } \\
\& 2,4-D\end{array}$ & $\begin{array}{l}95 \% \mathrm{Cl} \\
\text { for OR } \\
\text { adjusted } \\
\text { for age } \\
\& 2,4-\mathrm{D}\end{array}$ & $\begin{array}{l}\text { OR } \\
\text { adjusted } \\
\text { for age \& } \\
\text { organo- } \\
\text { phos- } \\
\text { phates }\end{array}$ & $\begin{array}{c}95 \% \mathrm{Cl} \\
\text { for OR } \\
\text { adjusted } \\
\text { for age \& } \\
\text { organo- } \\
\text { phos- } \\
\text { phates }\end{array}$ & $\begin{array}{c}\text { OR } \\
\text { adjusted } \\
\text { for age, } \\
2,4-D \& \& \\
\text { organo- } \\
\text { phos- } \\
\text { phates }\end{array}$ & $\begin{array}{c}95 \% \mathrm{Cl} \\
\text { for OR } \\
\text { adjusted } \\
\text { for age, } \\
2,4-\mathrm{D} \& \\
\text { organo- } \\
\text { phos- } \\
\text { phates }\end{array}$ \\
\hline \multicolumn{11}{|l|}{ Nebraska } \\
\hline $\begin{array}{l}\text { Without atrazine use } \\
\text { With atrazine use }\end{array}$ & $\begin{array}{r}397 \\
69\end{array}$ & $\begin{array}{l}98 \\
29\end{array}$ & 1.7 & $1.0-2.7$ & 1.1 & $0.6-2.0$ & 0.7 & $0.4-1.4$ & 0.7 & $0.3-1.3$ \\
\hline \multicolumn{11}{|l|}{ lowa } \\
\hline $\begin{array}{l}\text { Without atrazine use } \\
\text { With atrazine use }\end{array}$ & $\begin{array}{r}218 \\
90\end{array}$ & $\begin{array}{r}103 \\
52\end{array}$ & 1.2 & $0.8-1.8$ & 1.5 & $0.9-2.5$ & $\dot{1.3}$ & $0.7-2.2$ & 1.6 & $0.9-2.9$ \\
\hline \multicolumn{11}{|l|}{ Minnesota } \\
\hline $\begin{array}{l}\text { Without atrazine use } \\
\text { With atrazine use }\end{array}$ & $\begin{array}{r}267 \\
53\end{array}$ & $\begin{array}{r}124 \\
36\end{array}$ & 1.4 & $0.9-2.3$ & 1.4 & $0.9-2.4$ & 1.3 & $0.8-2.2$ & 1.3 & $0.8-2.2$ \\
\hline \multicolumn{11}{|l|}{ Kansas } \\
\hline $\begin{array}{l}\text { Without atrazine use } \\
\text { With atrazine use }\end{array}$ & $\begin{array}{r}625 \\
37 \\
\end{array}$ & $\begin{array}{r}120 \\
13 \\
\end{array}$ & 2.1 & $1.0-4.1$ & 1.6 & $0.8-3.6$ & 2.5 & $1.1-5.4$ & 1.9 & $0.8-4.5$ \\
\hline \multicolumn{11}{|l|}{ Totala } \\
\hline $\begin{array}{l}\text { Without atrazine use } \\
\text { With atrazine use }\end{array}$ & $\begin{array}{r}1507 \\
249\end{array}$ & $\begin{array}{l}445 \\
130\end{array}$ & $\dot{1.5}$ & $1.1-1.9$ & 1.4 & $1.0-1.8$ & $\dot{1.2}$ & $0.9-1.7$ & 1.2 & $0.9-1.7$ \\
\hline
\end{tabular}

a The data for all of the states combined have been adjusted for age, state, and the specified pesticide exposures.

Table 5. Number of non-Hodgkin's lymphoma cases and referents and odds ratios (OR) according to characteristics of atrazine use among male farmers in Nebraska, adjusted for age and use of 2,4-dichlorophenoxyacetic acid (2,4-D) and organophosphate insecticides.

\begin{tabular}{|c|c|c|c|c|c|c|c|}
\hline & $\begin{array}{l}\text { Referents } \\
\text { (N) }\end{array}$ & $\begin{array}{l}\text { Cases } \\
\text { (N) }\end{array}$ & $\begin{array}{c}\text { OR } \\
\text { adjusted } \\
\text { for } \\
\text { age }^{a}\end{array}$ & $\begin{array}{c}\text { OR } \\
\text { adjusted } \\
\text { for } \\
\text { age }^{b}\end{array}$ & $\begin{array}{c}\text { OR } \\
\text { adjusted } \\
\text { for age \& } \\
2,4-D^{b}\end{array}$ & $\begin{array}{c}\text { OR } \\
\text { adjusted } \\
\text { for age \& } \\
\text { organo- } \\
\text { phosphates }^{b}\end{array}$ & $\begin{array}{c}\text { OR } \\
\text { adjusted } \\
\text { for age, } \\
\text { 2,4-D \& } \\
\text { organo- }^{\text {organo }} \\
\text { phosphates }^{b}\end{array}$ \\
\hline Nonfarmers & 184 & 54 & 1.0 & . & . & . & . \\
\hline \multicolumn{8}{|l|}{ Farmers } \\
\hline No atrazine use & 397 & 98 & 0.8 & 1.0 & 1.0 & 1.0 & 1.0 \\
\hline \multicolumn{8}{|c|}{ Duration of atrazine use } \\
\hline $\begin{array}{l}1-5 \text { years } \\
6-15 \text { years } \\
16-20 \text { years } \\
\geq 21 \text { years }\end{array}$ & $\begin{array}{r}14 \\
20 \\
8 \\
11\end{array}$ & $\begin{array}{l}4 \\
5 \\
5 \\
7\end{array}$ & $\begin{array}{l}0.9 \\
0.8 \\
2.0 \\
2.0\end{array}$ & $\begin{array}{l}1.2 \\
0.9 \\
2.7 \\
2.5\end{array}$ & $\begin{array}{l}0.8 \\
0.7 \\
1.8 \\
1.9\end{array}$ & $\begin{array}{l}0.5 \\
0.6 \\
0.9 \\
1.0\end{array}$ & $\begin{array}{l}0.4 \\
0.5 \\
0.6 \\
0.8\end{array}$ \\
\hline \multicolumn{8}{|c|}{$\begin{array}{l}\text { Average annual days } \\
\text { personally handled } \\
\text { atrazine }\end{array}$} \\
\hline $\begin{array}{l}1-5 \text { d/year } \\
6-20 \text { d/year } \\
\geq 21 \text { d/year }\end{array}$ & $\begin{array}{r}20 \\
17 \\
1\end{array}$ & $\begin{array}{l}7 \\
8 \\
1\end{array}$ & $\begin{array}{l}1.2 \\
1.4 \\
3.8\end{array}$ & $\begin{array}{l}1.3 \\
1.8 \\
3.1\end{array}$ & $\begin{array}{l}0.9 \\
1.2 \\
2.4\end{array}$ & $\begin{array}{l}0.7 \\
0.8 \\
1.3\end{array}$ & $\begin{array}{l}0.6 \\
0.7 \\
1.4\end{array}$ \\
\hline \multicolumn{8}{|c|}{$\begin{array}{l}\text { Latency: (year of first use } \\
\text { of atrazine) }\end{array}$} \\
\hline $\begin{array}{l}\leq 1965 \\
>1966\end{array}$ & $\begin{array}{l}35 \\
18\end{array}$ & $\begin{array}{l}10 \\
10\end{array}$ & $\begin{array}{l}1.0 \\
1.9\end{array}$ & $\begin{array}{l}1.1 \\
2.3\end{array}$ & $\begin{array}{l}0.8 \\
1.6\end{array}$ & $\begin{array}{l}0.5 \\
1.2\end{array}$ & $\begin{array}{l}0.4 \\
1.0\end{array}$ \\
\hline
\end{tabular}

a Relative to nonfarmers.

b Restricted to farmers only, relative to farmers without atrazine use.

atrazine use specifically. Farmers who had used atrazine for more than 15 years had a twofold increased risk of non-Hodgkin's lymphoma, whereas no excess risk was seen for short-term users. When the analyses were restricted to farmers to allow for adjustment for other agricultural factors, the OR values for at- razine use increased slightly. Adjustment for the use of 2,4-D and organophosphate insecticides, particularly the latter, eliminated the risks associated with long-term atrazine use. Odds ratios fell below unity for all duration and frequency categories except the $\geq 21 \mathrm{~d}$ per year category, which was based on only 
one exposed patient and one exposed referent. Examination of the Nebraska data on the first year of use of atrazine revealed greater risks associated with shorter latency. After adjustment for other pesticides, the OR values were 0.4 and 1.0 for use before 1966 and after 1965 , respectively.

\section{Discussion}

By combining the data from three case-referent studies conducted in Nebraska, Iowa-Minnesota, and Kansas, we were able to evaluate the effects of agricultural practices for 993 non-Hodgkin's lymphoma cases in white males and for 2918 referents. This large number of subjects and the detailed nature of the study questionnaires allowed us to examine the risks for specific agricultural exposures with sufficient power to adjust for other agricultural and nonagricultural exposures.

In the combined data set, atrazine use was associated with a significant $40 \%$ excess risk of nonHodgkin's lymphoma. However, adjustment for the use of 2,4-D and organophosphate insecticides, pesticides associated with non-Hodgkin's lymphoma risk in previous analyses of the data from the contributing studies $(16-18)$, reduced the atrazine association for three of the four states. The most dramatic reduction in risk was in Nebraska, where the OR dropped from 1.7 to 0.7 . Nebraska was also the only state with detailed data on duration, frequen$c y$, and calendar years of use for atrazine. The ageadjusted data showed two- to threefold excesses in risk of non-Hodgkin's lymphoma for long-term and frequent atrazine users. When adjusted for other pesticides, the OR values were below unity for all but one duration or frequency category. Adjustment increased the risk only in Iowa, from 1.2 to $1.6(95 \%$ CI $0.9-2.9$ ). In two states and in all states combined, the risk to farmers who personally handled atrazine was lower than that to farmers who used atrazine in their farming operation but did not handle it themselves, contrary to what would have been expected if this chemical were causally associated with nonHodgkin's lymphoma. In our judgment, these data provide little evidence that atrazine is associated with non-Hodgkin's lymphoma among white men.

It has been suggested (30) that pesticides, and herbicides in particular, may be playing a role in the large increase in the occurrence of non-Hodgkin's lymphoma that has taken place over the last 15 years in the United States (31), particularly in the Midwest (32), and in other developed countries (33). The factors responsible for this increase must be causally associated with non-Hodgkin's lymphoma and must have an increased prevalence of exposure. Although the use of atrazine has increased over this period, the results presented in this paper suggest that it is unlikely that atrazine exposure explains any appreciable amount of the observed increase in non-Hodgkin's lymphoma.

\section{References}

1. Economic Analysis Branch, Office of Pesticides Programs, US Environmental Protection Agency (US EPA). Pesticide industry sales and usage: 1989 market estimates. Washington, DC: US EPA, 1989.

2. National Coalition Against the Misuse of Pesticides. Atrazine. Pesticides You 1990;March:5-6.

3. Office of Water, Office of Pesticides and Toxic Substances, US Environmental Protection Agency (US EPA). National pesticide survey. Washington, DC: US EPA, 1990

4. Economic Research Service, US Department of Agriculture (USDA). Agricultural chemical usage: 1990 field crops summary. Washington, DC: USDA, 1991.

5. National Coalition Against the Misuse of Pesticides. Germany yanks atrazine. Pesticides You 1991;October:5.

6. Weisenburger DD, Joshi SS, Hickman TI, Babcook DM, Walker BA, Mirvish SS. N-Nitroso-atrazine (NNAT): synthesis, chemical properties, acute toxicity, and mutagenicity. In: American Association for Cancer Research. Proceedings of the American Association for Cancer Research; 1987 May 20-23; Atlanta (GA). Philadelphia, PA: American Association for Cancer Research, 1987:103.

7. Weisenburger DD, Joshi SS, Hickman TI, Walker BA, Lawson TA. Mutagenesis tests of atrazine and nitrosoatrazine: compounds of special interest to the Midwest. In: American Association for Cancer Research. Proceedings of the American Association for Cancer Research; 1988 May 25-28; New Orleans (LA). Philadelphia, PA: American Association for Cancer Research, 1988:421.

8. Mayhew DA, Taylor GD, Smith SH, Banas DA. Twenty-four month combined chronic oral toxicity and oncogenicity study in rats utilizing atrazine technical: conducted by American Biogenics Corporation for Ciba-Geigy Corporation: study number $410-1102$. Washington, DC: US Environmental Protection Agency, 1986. (Accession number 262714 -262727.)

9. Pinter A, Torok G, Borzsonyi M, Surjan A, Csik M, Kelecseni Z, et al. Long-term carcinogenicity bioassay of the herbicide atrazine in F344 rats. Neoplasma 1990;37:533-44.

10. Donna A, Betta PG, Gagliardi F, Chiazza GF, Gallareto M, Gabutto V. Preliminary experimental contribution to the study of possible carcinogenic activity of two herbicides containing atrazine-simazine and trifluralin as active principles. Pathologica 1981;73:707-21.

11. Donna A, Betta PG, Robutti F, Bellingeri D. Carcinogenicity testing of atrazine: preliminary report on a 13-month study on male Swiss Albino mice treated by intraperitoneal administration. Med Lav 1986;8: $119-21$.

12. International Agency for Research on Cancer (IARC). Occupational exposures in insecticide application, and some pesticides. Lyon: IARC, 1991:41-66. (IARC monographs on the evaluation of carcinogenic risks to humans; vol 53.)

13. Morseth SL. Fourteen-day repeated dose oral toxicity/ hormone study in female albino rats exposed to atrazine and diaminochlorotriazine: conducted by Hazelton Laboratories America, Inc, HLA no 483-268. Washington, DC: US Environmental Protection Agency, 1990. (Master record identification number 41510901.)

14. Donna A, Crosignani P, Robutti F, Betta PG, Bocca $\mathrm{R}$, Mariani N, et al. Triazine herbicides and ovarian epithelial neoplasms. Scand J Work Environ Health 1989;15:47-53.

15. Hoar SK, Blair A, Holmes FF, Boysen C, Robel RJ. Herbicides and colon cancer. Lancet 1985;1: $1277-8$. 
16. Hoar SK, Blair A, Holmes FF, Boysen CD, Robel RJ, Hoover R, et al. Agricultural herbicide use and risk of lymphoma and soft-tissue sarcoma. J Am Med Assoc 1986;256:1141-7.

17. Zahm SH, Weisenburger DD, Babbitt PA, Saal RC, Vaught JB, Cantor KP, et al. A case-control study of non-Hodgkin's lymphoma and the herbicide 2,4dichlorophenoxyacetic acid (2,4-D) in eastern Nebraska. Epidemiology 1990;1:344-56.

18. Cantor KP, Blair A, Everett G, Gibson R, Burmeister LF, Brown LM, et al. Pesticides and other agricultural risk factors for non-Hodgkin's lymphoma among men in Iowa and Minnesota. Cancer Res 1992;52: $2447-55$

19. Brown LM, Blair A, Gibson R, Everett GD, Cantor KP, Schuman LM, et al. Pesticide exposures and other agricultural risk factors for leukemia among men in Iowa and Minnesota. Cancer Res 1990;50:658591.

20. Brown LM, Everett GD, Gibson R, Burmeister LF, Schuman LM, Blair A. Smoking and risk of non-Hodgkin's lymphoma and multiple myeloma. Cancer Causes Control 1992;3:49-55.

21. Pottern LM, Linet M, Blair A, Dick F, Burmeister LF, Gibson R, et al. Familial cancers associated with subtypes of leukemia and non-Hodgkin's lymphoma. Leukemia Res 1991;15:305-14.

22. Hoar Zahm S, Blair A, Holmes FF, Boysen CD, Robel RJ. A case-referent study of soft-tissue sarcoma and Hodgkin's disease: farming and insecticide use. Scand J Work Environ Health 1988;14:224-30.

23. Zahm SH, Blair A, Holmes FF, Boysen CD, Robel RJ, Fraumeni JF Jr. A case-control study of soft-tissue sarcoma. Am J Epidemiol 1989;130:665-74.

24. Zahm SH, Weisenburger DD, Babbitt PA, Saal RC, Vaught JB, Blair A. Use of hair coloring products and the risk of lymphoma, multiple myeloma, and chronic lymphocytic leukemia. Am J Public Health 1992; 82:990-7.
25. Non-Hodgkin's Lymphoma Pathologic Classification Project. National Cancer Institute sponsored study of classification of non-Hodgkin's lymphomas: summary and description of a working formulation for clinical usage. Cancer 1982;49:2112-35.

26. Dick F, Van Lier S, Banks P, Frizzera G, Witrak G, Gibson R, et al. Use of the working formulation for non-Hodgkin's lymphoma in epidemiologic studies: agreement between reported diagnoses and a panel of experienced pathologists. JNCI 1987;78:1137-44.

27. Dick FR, Van Lier SF, McKeen K, Everett GD, Blair A. Nonconcurrence in abstracted diagnoses of nonHodgkin's lymphoma. JNCI 1987;78:675-8.

28. Waksberg J. Sampling methods for random digit dialing. J Am Stat Assoc 1978:73:40-6.

29. Boice JD Jr, Lubin JH, Preston DL. EPITOME: Epidemiologic analysis with a personal computer, programs compiled at the NCI Epidemiology and Biostatistics Program. Bethesda, MD: National Cancer Institute, 1990.

30. Zahm SH, Blair A. Pesticides and non-Hodgkin's lymphoma. Cancer Res 1992;52 suppl:5485s-8s.

31. Ries LAG, Hankey BF, Edwards BK. Cancer statistics review, 1973-1987. Washington, DC: US Department of Health and Human Services, National Institutes of Health, 1990. (Report; no NIH 90-2789.)

32. Pickle LW, Mason TJ, Howard N, Hoover R, Fraumeni JF Jr. Atlas of US cancer mortality among whites: $1950-1980$. Washington, DC: US Department of Health and Human Services, National Institutes of Health, 1987. (Report; no NIH 87-2900.)

33. Davis DL, Hoel D, Fox J, Lopez A. International trends in cancer mortality in France, West Germany, Italy, Japan, England and Wales, and the USA. Lancet 1990;336:474-81.

Received for publication: 25 June 1992 